\title{
EXPORT PROSPECTS FOR AN APPLIED PRODUCT ACCORDING TO INTEGRATED ENVIRONMENTAL DESIGN STANDARDS
}

\author{
Noha Sayed Mohamed Afifi ${ }^{1}$, Tamer Mohamed Helmy Shaker ${ }^{2, *}$ \\ ${ }^{1}$ Decoration Department, Higher Institute of Applied Arts, The Fifth Settlement \\ ${ }^{2}$ Interior Design and Furniture Department, The Higher Institute of Applied Arts, The Fifth District
}

\begin{abstract}
The ecosystem establishes a model for reducing the sources of environmental pollution and designing technical rules to reduce energy consumption for the manufacture of products that do not negatively affect the state of the environment, and limit non-renewable energy consumption, and it has industrial and economic advantages that positively affect the environment. And that as defined by the United Nations Environment Program for the term "sustainable development" is development in harmony with the environment at the regional and local level, with the rational use of natural resources and through appropriate technology. Sustainability aims to benefit from the resources of the current environment and its continuity through subsequent generations in a moderate manner, through the selection and selection of natural materials, the manufacture of renewable and re-used products, the recycling of products, and the establishment of certified environmental institutions to monitor and grant official certificates of the quality of these products. Sustainable design is a theory based on thought and the application of technology as it is concerned with the parts of design down to the whole, preserving the health of individuals and the environment.
\end{abstract}

Keywords

EXPORT - APPLIED PRODUCT- INTEGRATED ENVIRONMENTAL-DESIGN STANDARDS.

\section{Introduction}

Environmental products are manufactured without the use of any chemical inputs harmful to the environment in all production stages until they reach the consumer with high quality. It branches out from the environmental design systems and calls for the use of natural and environmentally friendly materials, the exclusion of materials that have been proven to have a harmful effect on health or the environment, and the search for alternatives to them. Environmental products are also made from natural raw materials available locally or regionally, especially those sustainable resources, especially materials that do not cause harmful emissions to health and the environment during the product stages and do not consume small amounts of energy. It is recyclable, does not cause high temperatures, is flexible and sophisticated, and uses friendly, development able, high-quality, and exportable technologies.

The quality of the natural raw material used in its manufacture is a major condition for the international export process, and it is free from any volatile organic compounds and pollutants for the environment. Recycled materials to manufacture environmentally friendly products. It is called the product Green Product due to its environmental benefits, including energy conservation, improved health and environmental cleanliness, reduced costs, flexibility, less environmental impacts during manufacturing, utilization of environmental resources in various production processes, as well as utilizing the rest of raw materials in recycling operations.

Green materials are the environmentally preferred materials that are natural materials that are renewable, and reusable, with modern design and technology visions.

Many environmental design trends emphasized that the environment is the main source for design and manufacturing, such as the design direction, ecological art, green design trend: and the trend of new nature: total beauty product: all the way to the integrated environmental product trend: which is based on appropriate inspiration from the environment. In manufacturing a high quality product. According to international environmental design standards, it is also competing for international export conditions through two models, one of which is for an Arab country (the United Arab Emirates), and the other is a European country (Canada), where both of them give export opportunities such as customs exemptions on the condition that the local component of the product meets $40 \%$, and the issuance of a certificate of origin.

Egypt can achieve a doubling of exports because it possesses renewable natural resources if compliance with the conditions and standards that ensure success in entering and maintaining the export market is taken into account. The research presents two proposed application models for exporting natural materials:

* Corresponding author: info@AppliedArts.edu.eg 


\section{EXPORT PROSPECTS FOR AN APPLIED PRODUCT ACCORDING TO INTEGRATED ENVIRONMENTAL DESIGN STANDARDS}

The first idea of the proposed applied product is: (an old Egyptian style shoes storage unit) according to the proposed environmental product direction for export.

The second idea is: (a lighting unit inspired by nature) according to an ecological product direction integrated with environmental materials.

Introduction

Egypt suffers from the problem of export production, and the inability of some applied products to compete in international markets .. For various reasons, the research is concerned with studying aspects of design, materials and implementation technology within that system, with the aim of opening new horizons for export, especially with international agreements that set the terms and specifications of the export and related product With the eco design system and the source environment. And from the keenness of many countries to reach a high-quality environmental product in accordance with sustainable development systems, the research includes the term environmental product and the classification of ecological materials, including natural local, and the treatment and alternative materials that are environmentally friendly. The research also provides an overview of the theories of environmental product design, such as the trend of ecological design, green design, the trend of new nature, and the total beauty product, concluding with the establishment of a new direction called "the integrated ecological product." Which aims to produce an environmentally compatible product in shape and materials for implementation in accordance with international environmental design standards as well as competing for export.

Two examples were identified for two importing countries, one of which is an Arab state, which is the "Emirates" and the other is a European country, which is Canada, as they set environmental conditions and standards for their export system. The research also presents two models for two applied producers according to the integrated ecological product trend and competing for export, and subject to environmental and export requirements.

\section{Research Problem}

- Some Egyptian applied products are not suitable for export.

- Overlooking the increase in the quality of the Egyptian applied product and its ability to be competitive and exported.

- Failure to apply environmental product specifications, especially with countries that impose environmental conditions for import.

The goal of research:

- Determine the specifications of the applied environmental product that is capable of exporting.

- Establishing a trend that aims to produce an environmentally friendly product in accordance with environmental design standards in an integrated manner.

- Presenting two applied models, which are in conformity with international standards, and for export abroad.

\section{Research Methodology}

The research is based on following the theoretical and analytical method, which is concerned with presenting the theoretical part and analyzing it, and the applied approach and is concerned with the two proposed applied models.

Hypothesis: Research Hypotheses

The research is supposed to present a study for an applied exportable product according to the integrated environmental product standards.

Results:

- Egypt can produce many environmental applied products as final or partial products, depending on local natural materials.

- Environmental products should be made from natural or environmentally friendly materials without using any chemical inputs.

Harmful to the environment at all stages of production.

- It is imperative to use technological methods in the environmental product to conserve environmental resources and product quality. - The ecological product provides an opportunity for open export to all countries of the world because of its environmental advantages in design. and implementation.

- Egyptian products can compete to export within the international market, provided that the conditions and standards are followed Export.

- The integrated environmental product direction accommodates the rest of the design trends in addition to being inspired by the environment, Product materials and implementation methods.

- Environmental export conditions to specific countries can be used in the development of local industries and their potential for export.

\section{Recommendations:}


- It is recommended that those in charge of sustainable environmental design study the characteristics of the environment, the cultural background, customs and traditions. And aesthetic values with the application of technological methods.

- Paying attention to local, renewable natural materials, as they are a major condition in the export of the product and its multiple sources.

- Paying attention to environmental products in terms of raw materials, manufacturing methods and product appearance as basic conditions for export.

- Respect for the environment must be taken into account and the study of every project that aims to invest in the environment, and the development of decisions the basic principles for preserving pollution of the environment and damage to its resources.

-The necessity of communication between specialists, researchers and factory owners to discover and benefit from every new emerging in the environment.

- The importance of having environmental and regulatory authorities to monitor, issue certificates, and set environmental product standards by official bodies.

\section{References}

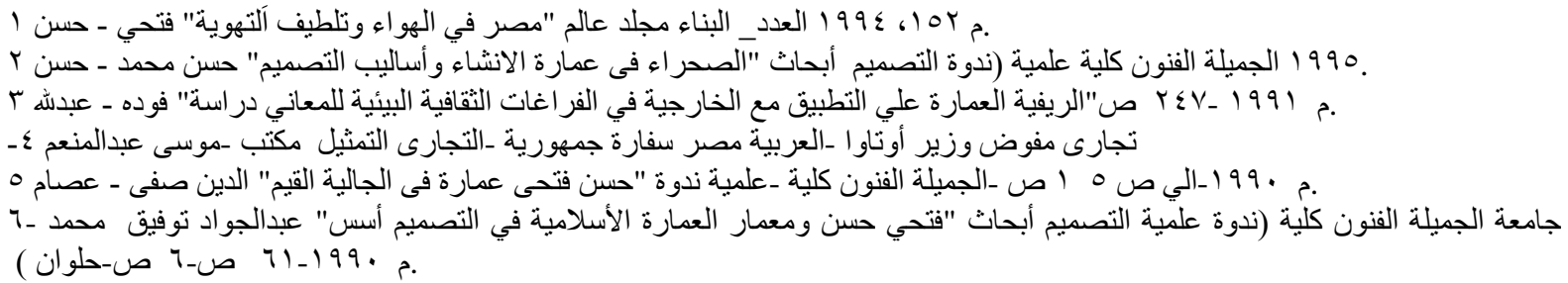

7- Earth Policy Institute Natural Systems, www.earth-policy.org, Data Center Retrieved on, 2009

8- Transmitted to the General Assembly as an Annex to document A/42/427 - Development and International Co-operation: Environment. Retrieved on:

9- Transmitted to the General Assembly as an Annex to document A/42/427 - Development and International Co-operation: Environment; Our Common Future, Chapter 2: Towards Sustainable Development; Paragraph 1 Retrieved 1 March 2010

10- United Nations General Assembly (2005). 2005 World Summit Outcome, Resolution A/60/1, adopted by the General Assembly on 15 September 2005. Retrieved on: 2009.

11- International Institute for Sustainable Development (2009). What is Sustainable Development?. Retrieved on: 2009

12- EurActiv (2004). "Sustainable Development: Introduction." Retrieved on: 2009.

13- Kates, R., Parris, T.\& Leiserowitz, A. (2005). "What is Sustainable Development?" Environment 47(3): 821. Retrieved on: 2009

14- Holling, C. S. (2000). "Theories for Sustainable Futures" Conservation Ecology 4(2): 7. Retrieved on: 2009

15- Porritt, J. (2006). Capitalism as if the world mattered. London: Earthscan. p. 46. ISBN 978-1-84407-193-7.

16- IUCN/UNEP/WWF (1991). "Caring for the Earth: A Strategy for Sustainable Living." Gland, Switzerland. Retrieved on: 2009

17- Markus J., Milne M.K., Kearins, K., \& Walton, S. (2006). Creating Adventures in Wonderland: The Journey Metaphor and Environmental Sustainability. Organization 13(6): 801-839. Retrieved on 2009

18- The Earth Charter Initiative (2000). "The Earth Charter." Retrieved on: 2009

" 19- Research titled "The Economics of Sustainable Architectural and Interior Design. academia.edu 20- alkhandq.blogspot.com/2014/12/GreenArchitectureSustainabilit Environment.

21- http://www.mawhopon.

22- https://www.scidev.net(Steps-convert-palm ).

23- en.wikipedia.org/wiki/Environmental_art.

24- https://ar.wikipedia.org

25- mawdoo3.com قش الأرزالئى

26- elshafie-shamco.com/ قش-الارز -ثروة 